Celtic: A Journal of Culture, English Language Teaching, Literature and Linguistics

Vol. 7, No. 1, June 2020.

E-ISSN: 2621-9158 P-ISSN:2356-0401

http://ejournal.umm.ac.id/index.php/celtic/index

\title{
THE EFFECT OF PROJECT BASED LEARNING TO THE STUDENTS' SPEAKING ABILITY
}

\author{
${ }^{1}$ Naajihah Mafruudloh*, ${ }^{2}$ Rahima Fitriati \\ ${ }^{1}$ Universitas Muhammadiyah Lamongan, Indonesia \\ ${ }^{2}$ Universitas Muhammadiyah Malang, Indonesia \\ *Corresponding Author: ichastudy07@gmail.com
}

\begin{abstract}
Project based learning (PBL) is an appropriate and applicable learning method in all levels of education. In this method, the lecturer acts as a facilitator or the one who takes a main role in teaching and learning process. The aim of PBL is to solve problems and develop students' critical thinking. It also encouraged the students' way of thinking in doing or creating something. This method was implemented in English for Management class at. It was expected to make the students to be more creative facilitated by a discussion, sharing, and collaboration work. The aim of this study was to describe the implementation of PBL in nonEnglish department class (Management department class) and to know the effect of PBL in students' speaking ability. There were 25 students selected as the sample. The methodology used pre-experimental design. Data were collected by observation to answer the first research question and test to answer the second research question. The acquired quantitative data were analysed statistically by paired sample T-test. The research found a significant effect of PBL to the students' speaking ability. It was also an effective methodology in teaching speaking because it made the students to be more active and innovative in doing the task and joining the class. Thus, it is strongly recommended to apply this teaching method in speaking class as an alternative way to improve students' speaking competency.
\end{abstract}

Keywords: ESP; PBL; Speaking Ability

\begin{abstract}
ABSTRAK
Project Based Learning (PBL) adalah metode pembelajaran yang tepat dan dapat diterapkan di semua tingkat pendidikan. Dalam metode ini, dosen bertindak sebagai fasilitator atau orang yang mengambil peran utama dalam proses belajar mengajar. Tujuan PBL adalah untuk memecahkan masalah dan mengembangkan pemikiran kritis mahasiswa. Hal ini juga mendorong cara berpikir mahasiswa dalam melakukan atau menciptakan sesuatu. Metode ini diterapkan dalam kelas Bahasa Inggris pada program studi manajemen. Hal ini diharapkan mampu membuat mahasiswa menjadi lebih kreatif ketika berdiskusi, berbagi, dan kerja kolaborasi. Tujuan dari penelitian ini adalah untuk menggambarkan implementasi PBL di kelas non- Bahasa Inggris (kelas Manajemen) dan untuk mengetahui pengaruh PBL pada kemampuan berbicara mahasiswa. Terdapat 25 mahasiswa yang dipilih sebagai sampel. Metodologi yang digunakan adalah pre-eksperimental. Data dikumpulkan dengan observasi dan tes. Data kuantitatif yang diperoleh dan dianalisis secara statistik dengan paired sample T-test. Pada penelitian ini ditemukan bahwa terdapat pengaruh yang signifikan dari PBL terhadap kemampuan berbicara. Metode ini efektif untuk diterapkan dalam mengajar kemampuan berbicara, karena hal ini membuat siswa menjadi lebih aktif dan inovatif dalam melakukan tugas. Oleh karena itu, sangat disarankan untuk menerapkan metode pengajaran ini di kelas berbicara sebagai cara alternatif untuk meningkatkan kompetensi berbicara mahasiswa.
\end{abstract}

Kata Kunci: ESP; PBL; Kemampuan Berbicara 
Mafruudloh, N. Fitriati, R (2020). The Effect of Project Based Learning to the Students' Speaking Ability. Celtic: A Journal of Culture, English Language Teaching, Literature, \& Linguistics, 7(1), 57-64.

\section{INTRODUCTION}

In English Language Teaching (ELT), the term project-based learning is considered as project or task. It could be held in the end of semester or certain times. The project has become a popular element within the process approach. It is the extended tasks which usually integrate language skills work by means of a number of activities which combine in working towards an agreed goal through planning; the gathering of information through reading, listening, interviewing, and observing; group discussion, problem solving; oral and written reporting; and display (Hedge, 2008).

In teaching learning process, English lecturers encountered some problems especially in teaching English in non-English department. The data were taken from the preliminary study that held by the researchers on 20 November 2019. The questions were given to 10 English lecturers randomly. It was from the students who have nonserious attitudes; long class time duration, bad physical classroom condition, inappropriate syllabus designs, attendance systems, and some psychological reasons like students' inhibition in learning English or their considering it as a burden. While in teaching method, they found problem in teaching method due to the lack of knowledge of language teaching tools, large classroom size, heterogeneous classes and secured desks, and such things. To overcome those problems, Ibrahim (2010), suggested that the lecturers must use student-centred approach that will help the students improve their communication skill, critical thinking, and cooperation in solving some problems.

Some previous studies that investigate the implementation of PBL have discovered its benefits for teaching and learning process. Ichsan (2016) found that PBL was applicable and effective for teaching speaking. He stated that it helped the students to have a creative thinking and good preparation on speaking class. In addition Simpson (2011) found that besides project based learning helps the lecturer to give task in extended period of time and systematically based on the specific need of the students, project based learning also gives benefits to the students, such enhancing teamwork skill, higher-order thinking skill, presentation skill, and increasing self confident in using the language. Baş (2011) has also conducted a research to investigate the effect of project based learning through experimental research. He reported that the students as the experimental group which is they are taught by PBL as seen from the average score, have higher score than control group, while statistically, the result of the analysis using SPSS show the significant differences between experimental group and control group. While, Gültekin (2005) investigated the effect of PBL on learning outcomes in primary education. The study found the significant effect as count as statistically which the experimental group higher score than experimental group. While qualitatively, project based learning approach is enjoyable and motivate students and let students to have fun while they are studying.

The implementation of PBL in non-English department is needed to be conducted concerning the problems that usually occur in teaching and learning activity. It is not only come from students, but also the lecturer that may become an obstacle (Abdulaziz, 2012). Furthermore, this research is conducted in English for Management. Specifically, two research questions addressed in this study are: 1. How does lecturer implement the project based learning in non-English department students? 2. Is there any significant effect from Project based learning (PBL) to the students' speaking ability? 
Celtic: A Journal of Culture, English Language Teaching, Literature and Linguistics

Vol. 7, No. 1, June 2020.

E-ISSN: 2621-9158 P-ISSN:2356-0401

http://ejournal.umm.ac.id/index.php/celtic/index

\section{METHOD}

The research design used mixed methods. Mixed methods research is an approach to inquiry combine two research method, qualitative and quantitative to collect data, assimilate the two forms data using distinct designs that may involve philosophical assumptions and theoretical frameworks (Creswell, 2014). The researcher used mixed methods research in combining qualitative data and quantitative data as well. Qualitative method in this research dominated the research methodology, because the researcher used documentation and observation as instrument data collection, and the data were changed into transcript, typically characteristic of qualitative method. This research also used numbers, percentage as the result, typically characteristic of quantitative method. This was needed to provide complete research and valid finding result. Observation was an instrument to answer the first research question. Then to answer the second research question the researcher used experimental research design, because it used to know the significant effect of PBL for the students' speaking ability and observation to answer the first research question. The first research question was described on how the lecturer implemented the PBL in teaching English subject in Management class. Then the second is to distinguish the significance effect of Project based learning to the students' speaking ability.

The researchers used purposive sampling. It selected based on the characteristics of a population and the objective of the study. The subjects were management students that consist of 25 students. In this study, the techniques to collect the data were observation and test. The observation was employed to capture all the phenomena that happened in the classroom when lecturer taught English class. The researcher became a participant observer because she was also teaching and being involved in teaching and learning process. The test was employed to assess the students speaking ability.

In data analysis, the data collected from observation that was analysed in qualitative method and quantitative data was obtained from the test. The validity and reliability of the instruments were tested as well. Then, for the second research question was done by using paired sample T-test.

\section{FINDING AND DISCUSSION}

This part would answer two research questions. The first research question obtained by using observation instrument, and the second research question used Test.

\section{The Project based learning (PBL) implementation}

In this study, the implementation of project based learning was conducted in Management department. It was for helping the lecturer to face and solve the problems in speaking class. Based on the syllabus, after having teaching and learning process, the students were expected to be able to demonstrate transactional dialogue in social life. Therefore, in this study, the implementation of PBL would be accordance with the basic competence of the syllabus which emphasized on students' speaking skill.

The researcher designed a project in which the students felt common to do, and especially in this study, the project was to make a video that contains some material that they had learn in the first semester, such as promoting product, news report, procedural text, etc. The students should choose one of them. Then they had to share their project on their social media account. The lecturer systematically implemented project based 
Mafruudloh, N. Fitriati, R (2020). The Effect of Project Based Learning to the Students' Speaking Ability. Celtic: A Journal of Culture, English Language Teaching, Literature, \& Linguistics, 7(1), 57-64.

learning in several meetings and adjusted with the syllabus into several steps, those are; start with essential question, design a plan for the project, create a schedule, monitor the students and progress of the project, assess the outcome, and evaluate the experience.

\section{Starting with the essential question}

In the first meeting, lecturer actually applied two steps of the PBL. It started with essential question and designed a plan for the project. The lecturer prepared the project by firstly asking about what task the students had in the previous meeting. The lecturer tried to drive the student to the extended task by connecting with the previous task in which the task was already prepared for the class. The dialog occurred between lecturer and students. It indicated that the lecturer wanted to bridge the project with students' activity in previous meeting in order to eliminate assumption that the project is something separated from the students' daily tasks. Moreover, from this dialog the lecturer wanted to give awareness that the project they had was from their self. Hence, the important question direct to the project.

\section{Designing a plan for the project}

Next, the lecturer implemented the second step of PBL. It was designing a plan for the project by asking student to negotiate and discuss with their friends. This step was also conducted in the first meeting after the students completing a guided task from the lecturer. In this part, the lecturer gave some description and directions how to do the project. The topics were given from the lecturer, in this part the students would choose the most proper and interesting topic from themselves. In addition, the topics were related to their field of study materials that were studied before. From the discussion, it is noted that the students were the non-English department, so, they felt hard to speak in English, and the lecturer felt difficulty at asking students to speak more in English. The students also might speak in Bahasa. In this part the lecturer facilitated them.

\section{Creating a schedule}

Creating schedule as the third step of PBL was applied by the lecturer in the second meeting. At first, the lecturer asked the students to decide the planning of their schedule. The lecturer asked students to discuss their project. In this point, the students were asked in making project individually, but some of students may to help their friends in doing the project. Then in the discussion, the lecturer explained what the students need to decide, like the date of the processing and material the students might need in the project, okay you have to decide the planning, and decide what date of every planning, the job description, and finishing" (she continued by explaining the material might be included in the discussion). "Do not forget to take a note, what is your activity and the time also. The lecturer used English and Bahasa Indonesia to ensure all the students understood about what they needed to discuss. The lecturer actively supervised the students' discussion, answered the question related to the project and asked to students to present their planning in front of the class.

\section{Monitoring the students and the progress of the project}

In the third meeting, the lecturer specially designed the class to apply the fourth step of PBL; monitor the students and the progress of the project. The lecturer created 
Celtic: A Journal of Culture, English Language Teaching, Literature and Linguistics

Vol. 7, No. 1, June 2020.

E-ISSN: 2621-9158 P-ISSN:2356-0401

http://ejournal.umm.ac.id/index.php/celtic/index

an interview to the students to check their progress in the project and scored the students' performance. In this part, the lecturer considered a deadline when the students had to submit and share their project in social media. Besides the content and how they were speak up, it is also important to have an evaluation to their media social feedback, such as how many account who give 'like' on the project that they posted.

\section{Assessing the outcome}

The outcome of the students in conducting project was closely related to this step. Assessing the outcome as the fifth step of PBL had different application. In this meeting, the lecturer assessed the students' outcome in negotiating something through discussion. The lecturer used live monologue or presentation to assess the students' ability to perform social communication. In this part, the lecturer assessed four components of speaking, such as content, grammar, vocabulary, and pronunciation. Before uploading the project on their social media, the lecturer tried to remind them about each material. How should the content made, the content duration, etc.

\section{Evaluating the experience}

In the last meeting, the lecturer asked the students to present their project in front of the class. They had to explain point by point to make other students understand their project before uploading it to the social media. In this chance, the lecturer applied two things; assess the outcome of the students that was students' ability in delivering and responding the opinion and the last step of PBL that is evaluating the experience.

\section{The effectiveness of Project based learning (PBL) to the students' speaking ability}

The pre-test was conducted before the students got the treatment. In other words, pre-test was done to compare the speaking ability obtained by all the students with the post-test result. The pre-test was followed by 25 students in Management class. It was conducted on 20 September 2019 and for the post test was conducted on 19 December 2019, exactly before the students had their final test.

Table 1. Paired Sample Statistics

\begin{tabular}{llllll}
\hline & Mean & N & Std. Deviation & $\begin{array}{l}\text { Std. } \\
\text { Mean }\end{array}$ & Error \\
\hline Pair 1 & Pre-Test & 65.60 & 25 & 8.109 & 1.622 \\
& Post-test & 76.08 & 25 & 9.340 & 1.868 \\
\hline
\end{tabular}

The table showed that the students' mean score in the pre-test was 65.60 and the post test was 76.08. It means that there was an improvement after implementing the project based learning method. The result of the post-test showed that the mean score which the students who had been taught using PBL, was higher than the students who had not been taught using PBL yet. To make it clear, the difference between the two tests should be computed by using paired t-test that will be addressed in the following part respectively. 
Mafruudloh, N. Fitriati, R (2020). The Effect of Project Based Learning to the Students' Speaking Ability. Celtic: A Journal of Culture, English Language Teaching, Literature, \& Linguistics, 7(1), 57-64.

Table 2. The result of paired sample t-test

\begin{tabular}{|c|c|c|c|c|c|c|c|c|c|}
\hline \multicolumn{10}{|c|}{ Paired Sample Test } \\
\hline & \multicolumn{9}{|c|}{ Paired Differences } \\
\hline \multirow[b]{2}{*}{ Pair 1} & \multirow[b]{2}{*}{ Pre test- Post test } & \multirow{2}{*}{$\begin{array}{l}\text { Mean } \\
-10.480\end{array}$} & $\begin{array}{l}\text { Std. } \\
\text { Deviation }\end{array}$ & $\begin{array}{l}\text { Std } \\
\text { Error } \\
\text { Mean }\end{array}$ & \multicolumn{2}{|c|}{$\begin{array}{c}95 \% \text { Confidence } \\
\text { Interval of } \\
\text { Difference }\end{array}$} & $t$ & $d f$ & $\begin{array}{l}\text { Sig } \\
(2- \\
\text { tailed })\end{array}$ \\
\hline & & & 13.229 & 2.646 & $\begin{array}{l}\text { Lower } \\
-15.941\end{array}$ & $\begin{array}{l}\text { Upper } \\
-5.019\end{array}$ & -3.961 & 24 & .001 \\
\hline
\end{tabular}

By using paired t-test analysis, the difference between the two means was computed. The criterion for the rejection or acceptation of the null hypothesis is a level of significance .05 (95\% confidence). If the sig. value is less than to $.05(\mathrm{p}<0.05)$, it means that there is a statistically significant difference between two conditions (posttest and pre-test). According to the result the computation showed the significant value was 0.001 . Thus, the sig. (2-tailed) value was $0.001<0.05$ means that $\mathrm{H} 0$ was rejected and $\mathrm{H} 1$ is accepted. It implies that there is a significant effect of the PBL on the students' speaking ability. The result shows that the treatment was effective to make an important difference between the post-test and pre-test.

Based on the findings, it showed that there was significant effect of the project based learning to the students' speaking ability. There were several factors influenced PBL on the students' speaking ability. First, PBL is a communicative method for teaching speaking. In the first meeting, the lecturer asked the students to make a project related to their field of study. It is supported by Thomas (2000), that PBL is a learning model that provides an opportunity for the students to have active participation. The students learn by engaging the real word project and it is related to their major.

Second, the lecturer explained the directions clearly. The lecturer's role here was as a facilitator. She also showed what and how the students should do. It was related to Railsback (2002), PBL is an instructional strategy in which students have to plan, implement, and evaluate projects that have real world applications beyond the classroom. Then in this learning process, students played an active role to design their own learning. Teachers will still have opportunity to talk to the whole class, such as when the teachers have an announcement that every student needs to hear. As an example, in the first meeting students need pre-knowledge about the material that will be learnt. After that, in order to give a project, the lecturer asked the students to use social media as a way to show their project. From this way, the students developed skills for living in a knowledge-based and highly technological society. Solving highly complex problems requires students to have both fundamental skills and Digital Age skills. With this combination of skills, students become directors and managers of their learning, guided and mentored by skilled teacher. Project-based learning brings real-life context and technology to the curriculum through project. Students are encouraged to become independent workers, critical thinkers, and lifelong learners.

The last, project based learning need long time in implementation. It takes more than two months. In this part, the lecturer could guide, facilitated, and gained information related to the students project, so they had a good preparation in doing the project. It also proved by Khoiriya (2015) she stated that PBL needs several time allotments. It means that the students could design and prepare their project well. In addition, the project based learning could be one of effective way in improving 
Celtic: A Journal of Culture, English Language Teaching, Literature and Linguistics

Vol. 7, No. 1, June 2020.

E-ISSN: 2621-9158 P-ISSN:2356-0401

http://ejournal.umm.ac.id/index.php/celtic/index

students' speaking ability. It also proved by Hartatik (2016), based on her classrom action research findings showed that Project based lerning could improve the students' speaking ability. She stated that PBL provided optimum opportunity for the students to explore and practice speaking skill so that they can improve their speaking ability.

Besides, the findings of the research show that this strategy had challenged the students to demonstrate their team -work ability. In contrast, Aldabbus (2014) stated that PBL was difficult to manage the classroom time appropriately because projects took more than the expected time. Additionally, the context where PBL was implemented played a fundamental role in hindering the process of using PBL effectively. As a result, some of the students did not ready with the PBL implementation. They also had lack of collaboration skill. Only a few students whose active and dominant in the classroom. Cintang, Setyowati, and Handayani (2018) also add that when the teacher had difficulties in implementing PBL, there were some factors. First, the teacher had wrong concept in PBL. It would made them difficult in mastery the project and had limited time. Then the teacher did not had good preparation. They should input the project during learning process, in the beginning of the semster for example. Those would minmized the difficulties in PBL implementation. Finally, PBL was important to implement in speaking skill, because there were important major characteristics of PBL that should students had. There were self-responsibility for thinking and learning, awareness of social responsibility, thinking and acting from the scientific perspective but in a practical application, and relating both group process and product with professional practice. (Rochamwati, 2015)

Implications were drawn from the research finding. The research came with a finding that there was a significant of PBL on the students' speaking skill. Moreover, this research implies that the use of PBL was needed in teaching speaking. It could make the students to be more active and innovative in creating ideas. Considering the finding drawn above, it implies that the use of PBL was capable to promote the improvement of students' speaking skill in which it can be seen from the progress of the students' speaking scores after given a treatment using PBL. It was expected that the English teachers were highly recommended to utilize the PBL on the teaching English to improve the students' speaking skill. Students are motivated and relaxed in learning process when they are taught using PBL. Therefore, it implies that the use of PBL also could enhance the students' interest and help them to explore and transmit their ideas into spoken or oral communication. It was also proposed to help the students accomplish the material concepts well by themselves so that the teacher learningcentered could be avoided.

\section{CONCLUSION}

Based on the result, the implementation of project-based learning in non-English department could help the students to accomplish the learning outcomes. As stated in syllabus, the outcome of the study was the ability to demonstrate transactional dialogue in social life. It also could promote cooperative and collaborative work to perform transactional dialog. The students could perform effective and meaningful communication as the language function since they communicated purposively to fulfil their comprehensive tasks. 
Mafruudloh, N. Fitriati, R (2020). The Effect of Project Based Learning to the Students' Speaking Ability. Celtic: A Journal of Culture, English Language Teaching, Literature, \& Linguistics, 7(1), 57-64.

The objective of this study was to know the effect whether project based learning is more effective to teach speaking skill than using direct instruction method. In order to gain the objective of the study, the researcher conducted pre-experimental research. From the computation of paired sample t-test, it shows that the result of the paired sample t-test was -3.96 . While $t$ table for $n=25$ in level of significant $\alpha=0,05$ was 0.001. It means that the Hi was accepted. Therefore, the project based learning has a significant effect to the students' speaking ability.

\section{REFERENCES}

Abdulaziz, M. S. (2012). Change from a General English Teacher to an ESP Practicioner: Issues and Challeges in Pakistan. Jurnal contemporary Research in Bussines, 9, pp. 1-12.

Aldabbus, S. (2018, March). PBL: Implementation and Challenges. International Journal and Education, Learning and development, 6, 71-79.

Baş, G. (2011). Investigating The Effects of Project-Based Learning on Students' Academic Achievement and Attitudes towards English Lesson. The Online Journal Of New Horizons In Education, 1, 1-15.

Cintang, N. S. (2018, February). The obstacles and Strategy of PBL Implementation in Elementary School. Journal of Education and Learning, 12, 7-15.

Creswell, J. (2014). Researcg Design: Qualitative, Quantitative, and Mixed Method 4th Edition. USA: SAGE Publication.

Gültekin, M. (2005). The Effect of PBL on learning Outcomes in the 5th Grade Social Studies Course in Primary Education. Educational Sciece: Theory and Practice, $5,548-556$.

Hartatik, S. F. (2016). Project Based Learning : an Offered solution for Speaking Class. Celtic, 2.

Hedge, T. (2008). Teaching and Learning in the Language Classroom. Oxford: Oxford University Press.

Ibrahim, A. M. (2010). ESP at the Tertiary Level : Current Situation, Aplication, and Expectation. English Language Teaching, 3, 200-204.

Ichsan, M. H. (2016). media.neliti.com. Retrieved March 10, 2020, from https://media.neliti.com/media/publications/213975-none.pdf

Khoiriya, S. R. (2015, June). Project Based Learning Method in Teaching English Speaking Skill for Grade 11 of SMAN 3 Malang. Celttic, 2, 59-72.

Railsback, J. (2002). Project Based Instruction: Creating Excitement for Learning. Oragon: Northwest Regional Education Library.

Rochamwati, P. (2015). PBL to Raise Students' Speaking Ability: Its' Effect and Implementation ( A Mix method Research in Speaking II Subject). Koodifikasia, 9(1), 200-221.

Simpson, J. (2011). Integrating PBL in an English Language Tourism Classroom in a Thai University. Australian catolic University: Unpublished Disertation.

Thomas, J. (2000). A review of Research Project based Learning. San Rafael, California: Autodesk Foundation. 